\title{
Clinical Characteristics of Coronavirus Disease 2019
}

\section{(COVID-19): An Updated Systematic Review}

\author{
Zhangfu Fang ${ }^{\mathrm{a}, \mathrm{b}, \mathrm{t}}$, Fang $\mathrm{Yi}^{\mathrm{c} \#}$, Kang $\mathrm{Wu}^{\mathrm{c}}$, Kefang Lai ${ }^{\mathrm{c}}$, Xizhuo Sun ${ }^{\mathrm{a}}$, \\ Nanshan Zhong ${ }^{\mathrm{c} *}$, Zhigang Liu ${ }^{\mathrm{a}, \mathrm{b} *}$
}

a. Department of Respirology \& Allergy. Third Affiliated Hospital of Shenzhen University. Shenzhen (518020), China.

b. State Key Laboratory of Respiratory Disease for Allergy at Shenzhen University, Shenzhen Key Laboratory of Allergy \& Immunology, Shenzhen University School of Medicine, Shenzhen (518061), China.

c. State Key Laboratory of Respiratory Disease, National Clinical Research Center for Respiratory Disease, Guangzhou Institute of Respiratory Health, The First Affiliated Hospital of Guangzhou Medical University, Guangzhou Medical University, Guangzhou (510120), China

\section{*Correspondence :}

\section{Nanshan Zhong}

Professor, State Key Laboratory of Respiratory Disease,

Guangzhou Institute of Respiratory Health,

the First Affiliated Hospital of Guangzhou Medical University.

151 Yanjiang Rd., Guangzhou (510120), China

Email: nanshan@ vip.163.com; Tel: 8620-83062718; Fax: 8620-83062729

\section{Zhigang Liu}

Professor, the State Key Laboratory of Respiratory Disease for Allergy,

Shenzhen University School of Medicine, Shenzhen University.

1066 Xueyuan Rd., Nanshan district of Shenzhen (518061), China

Email: 1zg195910@ 126.com; Tel: 86755-86671907; Fax:86755-86671906

\#The authors contribute equally to this work.

Running title: Clinical characteristics of COVID-19 


\begin{abstract}
OBJECTIVE

Clinical characteristics of novel coronavirus disease (COVID-19) have been described in numerous studies but yielded varying results. We aimed to conduct a systematic review on scientific literatures and to synthesize critical data on clinical traits of COVID-19 from its initial outbreak to pandemic.
\end{abstract}

\title{
METHODS
}

Systematic searches were conducted to identify retrospective observational study that contained clinical characteristics on COVID-19 through multiple databases. Two reviewers independently evaluated eligible publications. Data on clinical characteristics of COVID-19 were extracted and analyzed.

\section{RESULTS}

Seventy-two retrospective studies demonstrating the clinical characteristics of COVID-19 were included. A total of 3470 COVID-19 patients were synthesized to the final analysis in an unbiased manner. The most common symptom was fever (2878 [83.0\%]), and $63.4 \%$ of the patients presented fever as onset symptom. There were 2528 [88.2\%] of 2866 cases had abnormal lung findings on chest CT scan. Laboratory findings showed that 1498 [62.8\%] of 2387 cases had lymphopenia, and 1354 [64.8\%] of 2091 cases had an increased level of C-reactive protein (CRP). A total of 185 [11.5\%] patients were admitted to intensive care unit (ICU) while the overall case fatality rate (CFR) was 3.7\%. Compared to patients admitted outside of Hubei, China, those from Hubei had a significant higher ICU admission rate (21.9\% vs. 2.5\%, $p<0.001)$. Also, CFR attributed to COVID-19 was significantly higher in Hubei than that of non-Hubei admissions (10.4\% vs. $0.6 \%, p<0.001)$.

\section{INTERPRETATION}

This large patient-based systematic review presents a more precise profiling of the COVID-19 from its outbreak to current pandemic. Dynamic evolvements of COVID-19 are needed to be characterized in future studies.

Keywords: coronavirus pneumonia, COVID-19, clinical characteristic, systematic 
medRxiv preprint doi: https://doi.org/10.1101/2020.03.07.20032573; this version posted March 12, 2020. The copyright holder for this preprint (which was not certified by peer review) is the author/funder, who has granted medRxiv a license to display the preprint in perpetuity.

All rights reserved. No reuse allowed without permission.

review 


\section{Introduction}

In December 2019, a clustering pneumonia of unknown etiology occurred in Wuhan, Hubei Province, China ${ }^{1}$. The emerging disease has spread rapidly from Wuhan to other parts of China and to other countries ${ }^{2}$. Through a deep sequencing analysis, the virus responsible for this epidemic pneumonia has been designated as SARS-CoV-2 by International Committee on Taxonomy of Viruses (ICTV) ${ }^{3}$. The emerging disease caused by SARS-CoV-2 was named coronavirus disease 2019 (COVID-19) by WHO. By March 5, 2020, a total of 80,565 cases in China have been confirmed. Outside China, 14,768 cases of COVID-19 have been confirmed spanning in 85 countries, and the numbers are still on the rise ${ }^{4}$. What's worse is that a total of 1,716 healthcare workers in China have been infected, among which 5 have died by February 11, $2020^{5}$. Thus, this infectious disease has become a serious global health concern.

Since the outbreak of COVID-19, a large number of articles have been published reporting epidemiologic and clinical characteristics of this emerging disease. Huang et al. first reported 41 cases of COVID-19 in which $66 \%$ patients had a history of exposure to Huanan Seafood Market, Wuhan. Common symptoms of the case series were fever (98\%), cough (76\%), and myalgia or fatigue (44\%) with a case fatality rate (CFR) of $15 \%{ }^{6}$. Chen et al. in a subsequent study found that 99 cases of COVID-19 patients admitted to the same hospital (Jin Yin-tan Hospital, Wuhan) had similar trends of symptoms and CFR $(11 \%)^{7}$. Another case series analysis of 138 COVID-19 patients in Wuhan showed a relatively higher rate of fatigue symptom $(69.6 \%)$ but lower CFR (4.3\%) when compared to the above center ${ }^{8}$. Lastly, Xu et al. ${ }^{9}$ found in a multicenter-based retrospective study that clinical symptoms of patients in Zhejiang province are milder than those observed in Wuhan, China. Similarly, a nationwide multicenter study in China showed that patients with COVID-19 did not have a specific clinical symptom ${ }^{10}$. The clinical traits of COVID-19 are of great importance for the early identification of cases and for developing isolation and preventive strategies. However, there exist inconsistent findings of the clinical characteristics of 
COVID-19 among different studies, partly due to anthropogenic differences in patients enrolled and differences in sample size across different studies. Notably, variation in reporting descriptive data may lead to the misunderstanding of COVID-9 characteristics. In this updated systematic review, hence, we sought to address the heterogeneities among published retrospective studies and to synthesize the available data. We expect this critical review will provide insights to understand the clinical characteristics of COVID-19 in a more systematic manner.

\section{Methods}

\section{Identification of Documents on COVID-9}

Systematic searches were performed via the Medline database (PubMed) and Embase combining the terms (novel coronavirus OR 2019 novel coronavirus OR 2019-nCoV OR Coronavirus disease 2019 OR COVID-19 OR SARS-CoV-2). We also searched the database of Chinese Medical Journal full-text database (http://journal.yiigle.com/) for publications in Chinese using the above strategies. Searches were limited to publications from January 1, 2020 to March 1, 2020.

\section{Publication Selection}

Two of the authors (Z. F. and F. Y.) independently screened searching results to determine inclusion or exclusion of the articles. Disagreements were modulated by consulting another author as adjudicator (Z. L.). We included retrospective observational studies as long as they contain clinical characteristics of COVID-19 associated illness. If the patients came from the same hospital with overlapping cases, we only selected the publication containing greatest number of cases. The following publication were excluded: reviews articles, meta-analysis, perspectives, comments, consensus documents, and publications that were in the neither English nor Chinese. Also, publications with highly suspected but not laboratory confirmed cases were excluded.

\section{Literature Quality Evaluation, Data Collection and Statistical Analysis}


All included literatures were evaluated using the Newcastle-Ottawa Scale (NOS) ${ }^{11}$. The quality score of the literature ranged from lowest 0 to highest 9 . Total quality score of 0-3, 4-6, and 7-9 indicated poor, fair, and good studies, respectively. Information on baseline demographic data, medical and exposure history, symptoms and signs, underlying comorbidities, laboratory findings, chest computed tomographic (CT) scans and CFR were recorded. Based on the diagnostic gold standard for COVID-19 (positive RT-PCR assay for SARS-CoV-2), we synthesized data on demographic and clinical parameters in an unbiased manner. The proportion of each parameter was calculated by the following formula: (actual patient counts)/ (total patients confirmed using the gold standard) $\times 100 \%$. The $\chi 2$ test was used to compare the proportions. Statistical analyses were conducted using SPSS version 18 (IBM SPSS Statistics, IBM Corporation).

\section{Results}

\section{General Information on the Systemic Review}

A total of 1052 publications were retrieved using the search strategy. Seventy-two retrospective studies (including 22 case report, 20 case series, 3 case-control and 27 cross-sectional studies) that met the inclusion criteria were included in the final analysis (Figure 1). Of the selected publications, 51 were written in English while 21 were written in Chinese. The general information on eligible publications can be found in Table 1. Ten publications reported COVID-19 cases from outside of China in $\mathrm{USA}^{12}$, Germany ${ }^{13}$, South Korea ${ }^{14}$, Vietnam ${ }^{15}{ }^{16}, \mathrm{Nepal}^{17}$, Thailand ${ }^{18}$, Singapore ${ }^{19}$, Canada $^{20}$ and Italy ${ }^{21}$. The remaining cases were from China covering 31 provinces or provincial-level municipalities. Additionally, nine reports specifically targeted children and the remaining focused mainly on adult patients (including 2 on pregnant women). Admission time for COVID-19 patients was from December 11, 2019 to February 14, 2020. Quality assessment of the literatures showed that cross-sectional studies achieved a good quality (median score, 7.0) while case report/series were fair (median score, 6.0).

\section{Demographics and epidemiology of Selected Patients}


A total of 3,470 COVID-19 patients were included, of which 3,468 confirmed cases were based on the positive SARS-CoV-2 on RT-PCR assay while two cases ${ }^{25}$ were diagnosed according to coronavirus antibody detections. The age of the COVID-19 patients ranged from 17 days to 92 years old. Male gender accounted for 1822 (52.6\%) of the selected patients. Among 1,573 patients who were asked for smoking status, $208(13.2 \%)$ were self-reported smokers. Through a synthesized analysis, a total of 2182 cases $(76.0 \%)$ had a history of transmission exposures, i.e., the patients were either Wuhan residents or travelled to Wuhan within the past 14 days.

\section{Clinical Characteristics of COVID-19}

The most common symptom of COVID-19 was fever (2878 [83.0\%]), followed by cough (2102 [61.0\%]), fatigue (942 [37.9\%]), sputum production (720 [28.7\%]), dyspnea (412 [14.5\%]), muscle aches (477 [18.6\%]). Less common symptoms were headache (318 [11.8]), sore throat (289 [14.0\%]), gastrointestinal symptoms (anorexia, nausea or vomiting account for 185 [8.9\%]) and upper airway symptoms (rhinorrhea, sneeze or nasal congestion account for 162 [7.6\%]) and diarrhea (165 [6.1\%]) (Figure 2). Further analysis showed that only 1522 [63.4\%] of the patients had fever as their onset symptom.

Of the selected patients, 888 [31.5\%] cases co-existed with underlying chronic disorders, such as hypertension [13.3\%], diabetes [7.3\%], chronic obstructive pulmonary disease (COPD) [1.4\%], cardiovascular and cerebrovascular diseases [8.3\%], malignancy [1.5\%], chronic liver disease [2.1\%] and chronic kidney disease [0.7\%] (See Table 3 for details). Common complications of COVID-19 included acute respiratory distress syndrome (ARDS) (136 [8.9\%]), shock (29 [2.2\%]) and acute renal failure (30 [2.1\%]).

Radiological findings revealed that 2528 [88.2\%] of 2866 cases had abnormal presentations on chest CT (Figure 3A), with either bilateral or unilateral ground-glass/consolidative pulmonary opacities. Laboratory blood tests showed that 1498 [62.8\%] of 2387 cases had lymphopenia (lymphocyte count $<1.0 \times 10^{9} / \mathrm{L}$ ), while 1354 [64.8\%] of 2091 cases presented an increased level of C-reactive protein (CRP) (Figure 3 B-C). 


\section{Other Outcomes}

Collectively, a total of 185 [11.5\%] patients were admitted to intensive care unit (ICU) while the overall CFR was 3.7\% (Table 2). Our further analysis showed that COVID-19 patients admitted in Hubei province (Wuhan in particular) suffered from a significant higher ICU admission rate than that outside of Hubei, China (21.9\% vs. 2.5\%, $p<0.001)$. Also, CFR attributed to COVID-19 in Hubei province, China was significantly higher than that in non-Hubei, China (10.4\% vs. $0.6 \%, p<0.001)$.

\section{Discussion}

This review analyzed clinical data on COVID-19 patients enrolled retrospectively in published studies. These patients were admitted to hospitals between December 11, 2019 and February 14, 2020, which covered a period from COVID-19 outbreak to its global pandemic. To our knowledge, this updated systematic review analyzed the largest number of cases demonstrating the clinical characteristics of COVID-19, which covers ten countries. As of March 5, 2020, there have been 95,333 confirmed cases distributing over 86 countries $^{4}$. The rapid and wide spreading of the infection has clearly shown the pandemic potential of COVID-19, to which we should pay great attention.

Through literature searching and data extraction, we included 3,470 confirmed cases of COVID-19 based on the positive assays of SARS-CoV-2 on RT-PCR or antibody detection. The present study showed that the infected patients aged from 17-day to 92-year old. A recent report by Chinese Center for Disease Control and Prevention (China CDC) have shown that $86.6 \%$ the patients aged $30-79$ years ${ }^{5}$. This study together with China CDC report indicated that the general population, regardless of age, is susceptible to SARS-CoV-2 infection. The general ratio of male to female gender of the present study (1.10:1) is also similar to China CDC report (1.06:1), indicating that COVID-19 may not have a gender predisposition. Although 13.2\% of the selected patients had a history of smoking, we could not draw the conclusion that smokers are less susceptible to the viral infection than non-smokers, as the patients 
included in our analysis were from a sample pool that was not representative the general population by smoking status.

This systematic review showed that most of the patients $(76.0 \%)$ had a history of Wuhan-related exposures. This is of great importance for early quarantine for the subjects with emerging infectious disease when specific treatments are not available. Actually, we have learned from the SARS outbreak 17 years ago that early identification, early isolation and early management would lead to the stop of viral transmissions from human to human ${ }^{79}$. Collectively, there were $36 \%$ of the COVID-19 patients absent from fever as the onset symptom. In this case, such patients may have been ignored at the early stage if we focused heavily on fever examination for initial screening. Our composite analysis showed that fever remains the most common symptom (83.0\%) in patients with COVID-19. However, the proportion of fever is somewhat lower than that of other coronavirus related respiratory illness, such as SARS $(100 \%)^{80} 81$ or middle east respiratory syndrome (MERS) $(98 \%)^{82}$. Similarly, the accompanied symptoms of dyspnea (14.5\%) and diarrhea $(6.1 \%)$ are relatively less common in patients with COVID-19 than those seen in SARS and MERS ${ }^{87}$. More importantly, this study revealed an overall CFR of $3.7 \%$, which was quite similar to that reported by the WHO official statistics as of March 5, 2020 (CFR 3.7\%, 3,015 died of 80,565 cases) ${ }^{4}$. Nevertheless, the CFR of COVID-19 was much lower than that of SARS $(9.6 \%)^{83}$ and MERS $(37.1 \%)^{84}$. By far, the mechanisms underlying the varying symptoms and CFR for these three coronavirus-infected diseases are not fully understood. One reason may be that there were still some COVID-19 patients being treated in hospitals at the time of the manuscripts submitted, so the outcome (death or recovery) is not known yet. Additionally, we suppose that the varied tropism as well as virulence of these three coronaviruses may in part account for the discrepancies, which warrants further investigations.

According to the seven version Guidelines for the Diagnosis and Treatment of Novel 
Coronavirus Infection ${ }^{85}$, typical CT findings of early COVID-19 are characterized by multiple small patchy shadows and then developed into bilateral pulmonary ground-glass or consolidative opacities. In our summary, most of the patients (88.2\%) had abnormal findings in the lungs with chest CT scan. In some early cases of COVID-19, clear evidence of pneumonia has been shown on HRCT while X-ray radiographic findings are still normal ${ }^{51}$. Thus, chest CT scan should be routinely recommended for the early identification of COVID-19. Routine blood tests showed that $62.8 \%$ of COVID-19 patients had lymphopenia, of which the level is relatively lower than that of SARS ${ }^{86}$. Similarly, a large proportion (64.8\%) of COVID-19 patients had an increase level of CRP. Taken together, a combination of the epidemiologic history with auxiliary examinations, e.g., chest CT scan and blood tests, will improve the diagnostic accuracy for COVID-19.

Our further analysis revealed that patients admitted in Hubei province (Wuhan in particular) are facing much more severe situations (higher ICU admission rate and CFR) than those diagnosed in other parts of China. Reasons for the tough situations being caught in Hubei province might be as follows. Firstly, the human-to-human transmission of COVID-19 had not been cutting down at its early stage in Wuhan, Hubei province. Second, when encountering such a large number of infected patients, a limited healthcare workforce in Wuhan could not support to treat all patients at their mild or moderate stage. This might result in a higher rate of ICU admission or CFR. Since substantial number of patients as well as healthy residents have been kept in lockdown of Wuhan, great efforts are urgently needed to cutdown the virus transmission from COVID-19 patients to local healthy residents.

This systematic review has some limitations. First, due to the retrospective nature of selected literatures, not all clinical characteristics have been well documented. This have resulted in an inconsistence of the total numbers of each item being calculated. Second, some of the selected patients may not have discharged before the studies were finalized. This might have affected the clinical outcomes of COVID-19 to some 
extents. Third, since the disease is still ongoing, newly published data on COVID-19 might not be included at the time of manuscript submission. Nevertheless, we have summarized the largest number of patients demonstrating the clinical characteristics of COVID-19 in the present study. Finally, we could not determine the incubation periods of COVID-19 due to heterogeneity across studies in reporting the timeline of cases.

In summary, COVID-19 represents an emerging acute respiratory infection with various clinical presentations that share similarities as well as discrepancies with SARS and MERS. Combining clinical presentations with radiographic findings as well as blood tests may add value in early diagnosis and managements. Dynamic changes of clinical features in the course of COVID-19 are needed to be characterized in future studies. Since specific treatments are not available at the moment, urgent efforts should be taken to explore for this emerging disease. 
Acknowledgement: We would like to thank Prof. Junfeng (Jim) Zhang from Duke University and Dr. Mei Jiang from Guangzhou Institute of Respiratory Health for their kind help in refining the manuscript.

Contributors: ZF and FY contributed equally to this work. ZF, FY, and $\mathrm{KW}$ undertook the review. All authors contributed to the conception of the work and interpretation of the findings. ZF, FY, and ZGL drafted the manuscript. All authors read the manuscript and approved the final version. NSZ and ZGL acts as guarantor. The corresponding author attests that all listed authors meet authorship criteria and those did not meet the criteria have been omitted.

Funding: This systematic review presents independent research supported by the Shenzhen Science and Technology Peacock Team Project (Grant No. KQTD20170331145453160) and Shenzhen Nanshan District Pioneer Group Research Funds (Grant No. LHTD20180007)

\section{Competing interests:}

All authors have no potential conflicts of interest to declare.

Ethical approval: Not required. 


\section{References}

1. Wuhan Municipal Health Commission. Report of clustering pneumonia of unknown etiology in Wuhan City. Published December 31, 2019. http://wjw.wuhan.gov.cn/front/web/showDetail/2019123108989 Last accessed: March 05,2020

2. WHO. Coronavirus disease (COVID-2019) situation reports. https://www.who.int/emergencies/diseases/novel-coronavirus-2019/situation-reports

3. Gorbalenya, AE, Baker, SC, Baric, RS. et al. The species Severe acute respiratory syndrome-related coronavirus: classifying 2019-nCoV and naming it SARS-CoV-2. Nat Microbiol 2020. doi: 10.1038/s41564-020-0695-z

4. WHO. Coronavirus disease (COVID-2019) situation reports.

https://www.who.int/docs/default-source/coronaviruse/situation-reports/20200305-sitr ep-45-covid-19.pdf?sfvrsn=ed2ba78b 2 Last accessed: March 05, 2020

5. Wu Z, McGoogan JM. Characteristics of and Important Lessons From the Coronavirus Disease 2019 (COVID-19) Outbreak in China: Summary of a Report of 72314 Cases From the Chinese Center for Disease Control and Prevention. JAMA 2020. doi: 10.1001/jama.2020.2648

6. Huang C, Wang Y, Li X, et al. Clinical features of patients infected with 2019 novel coronavirus in Wuhan, China. Lancet 2020;395(10223):497-506. doi: 10.1016/S0140-6736(20)30183-5

7. Chen N, Zhou M, Dong X, et al. Epidemiological and clinical characteristics of 99 cases of 2019 novel coronavirus pneumonia in Wuhan, China: a descriptive study. Lancet 2020;395(10223):507-513. doi: 10.1016/S0140-6736(20)30211-7

8. Wang D, Hu B, Hu C, et al. Clinical Characteristics of 138 Hospitalized Patients With 2019 Novel Coronavirus-Infected Pneumonia in Wuhan, China. JAMA 2020 doi: 10.1001/jama.2020.1585

9. Xu XW, Wu XX, Jiang XG, et al. Clinical findings in a group of patients infected with the 2019 novel coronavirus (SARS-Cov-2) outside of Wuhan, China: retrospective case series. BMJ 2020:m606. doi: 10.1136/bmj.m606

10. Guan WJ, Ni ZY, Hu Y, et al. Clinical Characteristics of Coronavirus Disease 
2019 in China. $N$ Engl J Med 2020. doi: 10.1056/NEJMoa2002032

11. Stang A. Critical evaluation of the Newcastle-Ottawa scale for the assessment of the quality of nonrandomized studies in meta-analyses. Eur $J$ Epidemiol 2010;25(9):603-05.

12. Holshue ML, DeBolt C, Lindquist S, et al. First Case of 2019 Novel Coronavirus in the United States. N Engl J Med 2020 doi: 10.1056/NEJMoa2001191

13. Rothe C, Schunk M, Sothmann P, et al. Transmission of 2019-nCoV Infection from an Asymptomatic Contact in Germany. $N$ Engl J Med 2020 doi: 10.1056/NEJMc2001468

14. Kim JY, Choe PG, Oh Y, et al. The First Case of 2019 Novel Coronavirus Pneumonia Imported into Korea from Wuhan, China: Implication for Infection Prevention and Control Measures. J Korean Med Sci 2020;35(5):e61. doi: 10.3346/jkms.2020.35.e61

15. Van Cuong L, Giang HTN, Linh LK, et al. The first Vietnamese case of COVID-19 acquired from China. Lancet Infect Dis 2020. doi: 10.1016/s1473-3099(20)30111-0

16. Phan LT, Nguyen TV, Luong QC, et al. Importation and Human-to-Human Transmission of a Novel Coronavirus in Vietnam. N Engl J Med 2020. doi: 10.1056/NEJMc2001272

17. Bastola A, Sah R, Rodriguez-Morales AJ, et al. The first 2019 novel coronavirus case in Nepal. Lancet Infect Dis 2020. doi: 10.1016/S1473-3099(20)30067-0

18. Pongpirul WA, Pongpirul K, Ratnarathon AC, et al. Journey of a Thai Taxi Driver and Novel Coronavirus. N Engl J Med 2020. doi: 10.1056/NEJMc2001621

19. Kam KQ, Yung CF, Cui L, et al. A Well Infant with Coronavirus Disease 2019 (COVID-19) with High Viral Load. Clin Infect Dis 2020. doi: 10.1093/cid/ciaa201

20. Silverstein WK, Stroud L, Cleghorn GE, et al. First imported case of 2019 novel coronavirus in Canada, presenting as mild pneumonia. Lancet 2020;395(10225):734. doi: 10.1016/S0140-6736(20)30370-6

21. Albarello F, Pianura E, Di Stefano F, et al. 2019-novel Coronavirus severe adult respiratory distress syndrome in two cases in Italy: An uncommon radiological 
presentation. Int J Infect Dis 2020. doi: 10.1016/j.ijid.2020.02.043

22. Chen F, Liu Z, Zhang F, et al. First case of severe childhood novel coronavirus pneumonia in China. Chin $J$ Pediatr 2020(00):E005-E005. doi:10.3760/cma.j.issn.0578-1310.2020.0005. Article in Chinese.

23. Huang P, Liu T, Huang L, et al. Use of Chest CT in Combination with Negative RT-PCR Assay for the 2019 Novel Coronavirus but High Clinical Suspicion. Radiology 2020:200330. doi: 10.1148/radiol.2020200330

24. Cai J, Wang X, Ge Y, et al. First case of 2019 novel coronavirus infection in children in Shanghai. Chin $J$ Pediatr 2020; E002-E002. doi: 10.3760/cma.j.issn.0578-1310.2020.0002. Article in Chinese.

25. Zhang Z, Li X, Zhang W, et al. Clinical Features and Treatment of 2019-nCov Pneumonia Patients in Wuhan: Report of A Couple Cases. Virol Sin 2020. doi: $10.1007 / \mathrm{s} 12250-020-00203-8$

26. Lin X, Gong Z, Xiao Z, et al. Novel Coronavirus Pneumonia Outbreak in 2019: Computed Tomographic Findings in Two Cases. Korean J Radiol 2020;21(3):365-68. doi: $10.3348 / \mathrm{kjr} .2020 .0078$

27. Fang Y, Zhang H, Xu Y, et al. CT Manifestations of Two Cases of 2019 Novel Coronavirus (2019-nCoV) Pneumonia. Radiology 2020:200280. doi: 10.1148/radiol.2020200280

28. Deng H, Zhang Y, Wang Y. Two cases of 2019 novel coronavirus infection in children. Chin Crit Care Med 2020(00):E001-E001. Article in Chinese.

29. Yang Z, Li G, Dai X, et al. Three cases of novel coronavirus pneumonia with viral nucleic acids still positive in stool after throat swab detection turned negative. Chin J Dig 2020(00):E002-E002. Article in Chinese.

30. Wang Z, Chen X, Lu Y, et al. Clinical characteristics and therapeutic procedure for four cases with 2019 novel coronavirus pneumonia receiving combined Chinese and Western medicine treatment. Biosci Trends 2020 doi: 10.5582/bst.2020.01030

31. Zeng LK, Tao XW, Yuan WH et al. First case of neonate infected with novel coronavirus pneumonia in China. Chin J Pediatr 2020(00):E009-E009. doi: 10.3760/cma.j.issn.0578-1310.2020.0009. Article in Chinese. 
32. Xu X, Yu C, Zhang $\mathrm{L}$, et al. Imaging features of 2019 novel coronavirus pneumonia. Eur J Nucl Med Mol Imaging 2020 doi: 10.1007/s00259-020-04720-2

33. Li MD, Xu M, Zhan WQ, et al. Report of the first cases of mother and infant infections with 2019 novel coronavirus in Xinyang City Henan Province. Chin J Infect Dis 2020(00):E007-E007. DOI: 10.3760/cma.j.issn.1000-6680.2020.0007. Article in Chinese.

34. Xie X, Zhong Z, Zhao W, et al. Chest CT for Typical 2019-nCoV Pneumonia: Relationship to Negative RT-PCR Testing. Radiology 2020:200343. doi: 10.1148/radiol.2020200343

35. Huang WH, Teng LC, Yeh TK, et al. 2019 novel coronavirus disease (COVID-19) in Taiwan: Reports of two cases from Wuhan, China. J Microbiol Immunol Infect 2020 doi: 10.1016/j.jmii.2020.02.009

36. Yu P, Zhu J, Zhang Z, et al. A familial cluster of infection associated with the 2019 novel coronavirus indicating potential person-to-person transmission during the incubation period. J Infect Dis 2020. doi: 10.1093/infdis/jiaa077

37. Pan X, Chen D, Xia Y, et al. Asymptomatic cases in a family cluster with SARS-CoV-2 infection. Lancet Infect Dis 2020. doi: 10.1016/s1473-3099(20)30114-6 38. Hao W. Clinical Features of Atypical 2019 Novel Coronavirus Pneumonia with an initially Negative RT-PCR Assay. J Infect 2020. doi: 10.1016/j.jinf.2020.02.008

39. Wei J, Xu H, Xiong J, et al. 2019 Novel Coronavirus (COVID-19) Pneumonia: Serial Computed Tomography Findings. Korean J Radiol 2020. doi: 10.3348/kjr.2020.0112

40. Hao W, Li M, Huang X. First Atypical case of 2019 novel coronavirus in Yan'an, China. Clin Microbiol Infect 2020. doi: 10.1016/j.cmi.2020.02.011

41. Xu Z, Shi L, Wang Y, et al. Pathological findings of COVID-19 associated with acute respiratory distress syndrome. Lancet Respir Med 2020. doi: $10.1016 / \mathrm{S} 2213-2600(20) 30076-\mathrm{X}$

42. Lei J, Li J, Li X, et al. CT Imaging of the 2019 Novel Coronavirus (2019-nCoV) Pneumonia. Radiology 2020:200236. doi: 10.1148/radiol.2020200236

43. Liu P, Tan XZ. 2019 Novel Coronavirus (2019-nCoV) Pneumonia. Radiology 
2020:200257. doi: 10.1148/radiol.2020200257

44. Ruan ZR, Gong P, Han W, et al.A case of pneumonia in a 2019 novel coronavirus infected patient with twice-negative 2019-nCoV nucleic acid testing results within 8 days after onset. Chin Med J (Engl) 2020,133(00):E016-E016. doi: 10.3760/cma.j.issn.0366-6999.2020.0016

45. Chan JF, Yuan S, Kok KH, et al. A familial cluster of pneumonia associated with the 2019 novel coronavirus indicating person-to-person transmission: a study of a family cluster. Lancet 2020;395(10223):514-23. doi: 10.1016/s0140-6736(20)30154-9 46. Chen H, Guo J, Wang C, et al. Clinical characteristics and intrauterine vertical transmission potential of COVID-19 infection in nine pregnant women: a retrospective review of medical records. Lancet 2020. doi: 10.1016/S0140-6736(20)30360-3

47. Wei M, Yuan J, Liu Y, et al. Novel Coronavirus Infection in Hospitalized Infants under 1 Year of Age in China. JAMA 2020. doi: 10.1001/jama.2020.2131

48. Bai SL, Wang JY, Zhou YQ, et al. Analysis of the first cluster of cases in a family of novel coronavirus pneumonia in Gansu Province. Chin J Preventive Med 2020,54(04):E005-E005.DOI: 10.3760/cma.j.cn112150-20200204-00065. Article in Chinese.

49. Cai J, Xu J, Lin D, et al. A Case Series of children with 2019 novel coronavirus infection: clinical and epidemiological features. Clin Infect Dis 2020. doi: $10.1093 / \mathrm{cid} / \mathrm{ciaa} 198$

50. Gao T, He X, Su H, et al. Clinical characteristics of 11 cases of new coronavirus pneumonia. Chin J Clin Infect Dis 2020(00):E001-E001. Article in Chinese.

51. Zhang MQ, Wang XH, Chen YL, et al. Clinical features of 2019 novel coronavirus pneumonia in the early stage from a fever clinic in Beijing. Chin J Tuberc Respir Dis 2020;43(0):E013. doi: 10.3760/cma.j.issn.1001-0939.2020.0013. Article in Chinese.

52. Feng K, Yun YX, Wang XF, et al. Analysis of CT features of 15 Children with 2019 novel coronavirus infection. Chin J Pediatr 2020;58:E007. doi: 10.3760/cma.j.issn.0578-1310.2020.0007. Article in Chinese.

53. Chang, Lin M, Wei L, et al. Epidemiologic and Clinical Characteristics of Novel 
Coronavirus Infections Involving 13 Patients Outside Wuhan, China. JAMA 2020. doi: 10.1001/jama.2020.1623

54. Li Y, Xu S, Du T, et al. Clinical features of 2019 novel coronavirus infection patients and a feasible screening procedure. Chin J Emerg Med 2020(00):E007-E007. Article in Chinese.

55. Yang T, Yu X, He X, et al. Early clinical manifestations and pulmonary imaging analysis of patients with Novel coronavirus pneumonia. Chin J Emerg Med 2020(00):E005-E005. Article in Chinese.

56. Li YY, Wang WN, Lei Y, et al. Comparison of the clinical characteristics between RNA positive and negative patients clinically diagnosed with 2019 novel coronavirus pneumonia. Chin J Tuberc Respir Dis 2020(00):E023-E23. doi: 10.3760/cma.j.cn112147-20200214-00095. Article in Chinese.

57. Chung M, Bernheim A, Mei X, et al. CT imaging features of 2019 novel coronavirus (2019-nCoV). Radiology 2020:200230. doi: 10.1148/radiol.2020200230.

58. Chen L, Liu H, Liu W, et al. Analysis of clinical features of 29 patients with 2019 novel coronavirus pneumonia. Chin J Tuberc Respir Dis 2020(00):E005-E005. doi: 10.3760/cma.j.issn.1001-0939.2020.0005. Article in Chinese.

59. Song F, Shi N, Shan F, et al. Emerging Coronavirus 2019-nCoV Pneumonia. Radiology 2020:200274. doi: 10.1148/radiol.2020200274

60. Huang L, Han R, Yu PX et al. A correlation study of CT and clinical features of different clinical types of 2019 novel coronavirus pneumonia. Chin J Radiology 2020(00):E003-E003. doi:10.3760/cma.j.issn.1005-1201.2020.0003. Article in Chinese.

61. Kui L, Fang YY, Deng Y, et al. Clinical characteristics of novel coronavirus cases in tertiary hospitals in Hubei Province. Chin Med J (Engl) 2020. doi: 10.1097/CM9.0000000000000744.

62. Zhao R, Liang YG, Lin YR, et al. Clinical characteristics of 28 patients with novel coronavirus pneumonia. Chin J Infectious Dis 2020(00):E006-E006. doi: 10.3760/cma.j.issn.1000-6680.2020.0006. Article in Chinese.

63. Xu M, Li MD, Zhan WQ, et al. Clinical analysis of 23 cases of 2019 novel 
coronavirus infection in Xinyang City, Henan Province. Chin Crit Care Med 2020(02):E010-E010. doi: 10.3760/cma.j.issn.2095-4352.2020.02.000. Article in Chinese.

64. Shi H, Han X, Jiang N, et al. Radiological findings from 81 patients with COVID-19 pneumonia in Wuhan, China: a descriptive study. Lancet Infect Dis 2020. doi: 10.1016/s1473-3099(20)30086-4

65. Wu J, Liu J, Zhao X, et al. Clinical Characteristics of Imported Cases of COVID-19 in Jiangsu Province: A Multicenter Descriptive Study. Clin Infect Dis 2020. doi: 10.1093/cid/ciaa199

66. Xu X, Yu C, Qu J, et al. Imaging and clinical features of patients with 2019 novel coronavirus SARS-CoV-2. Eur J Nucl Med Mol Imaging 2020. doi: 10.1007/s00259-020-04735-9

67. Yang W, Cao Q, Qin L, et al. Clinical characteristics and imaging manifestations of the 2019 novel coronavirus disease (COVID-19):A multi-center study in Wenzhou city, Zhejiang, China. J Infect 2020. doi: 10.1016/j.jinf.2020.02.016

68. Wu J, Wu X, Zeng W, et al. Chest CT Findings in Patients with Corona Virus Disease 2019 and its Relationship with Clinical Features. Invest Radiol 2020. doi: 10.1097/rli.0000000000000670

69. Zhang JJ, Dong X, Cao YY, et al. Clinical characteristics of 140 patients infected by SARS-CoV-2 in Wuhan, China. Allergy 2020. doi: 10.1111/all.14238

70. Yang X, Yu Y, Xu J, et al. Clinical course and outcomes of critically ill patients with SARS-CoV-2 pneumonia in Wuhan, China: a single-centered, retrospective, observational study. Lancet Respir Med 2020. doi: 10.1016/s2213-2600(20)30079-5

71. Xu YH, Dong JH, An WM, et al. Clinical and computed tomographic imaging features of Novel Coronavirus Pneumonia caused by SARS-CoV-2. J Infect 2020. doi: 10.1016/j.jinf.2020.02.017

72. Liu RR, Zhu Y, Wu MY, et al. CT imaging analysis of 33 cases with the 2019 Novel coronavirus infection. Chin Med J 2020(00):E011-E11. doi:10.3760/cma.j.issn.0376-2491.2020.13.0. Article in Chinese.

73. Bernheim A, Mei X, Huang M, et al. Chest CT Findings in Coronavirus 
Disease-19 (COVID-19): Relationship to Duration of Infection. Radiology 2020:200463. doi: 10.1148/radiol.2020200463

74. Tian S, Hu N, Lou J, et al. Characteristics of COVID-19 infection in Beijing. $J$ Infect 2020. doi: 10.1016/j.jinf.2020.02.018

75. Liu W, Tao ZW, Lei W, et al. Analysis of factors associated with disease outcomes in hospitalized patients with 2019 novel coronavirus disease. Chin Med J (Engl) 2020(00):E010-E10. doi: 10.1097/CM9.0000000000000775

76. Wan Q, Shi AQ, He T, et al. Analysis of clinical features of 153 patients with novel coronavirus pneumonia in Chongqing. Chin $J$ Clin Infect Dis 2020(00):E008-E08. doi: 10.3760/cma.j.cn 115673-20200212-00030. Article in Chinese.

77. Wen K, Li WG, Zhang DW, et al. Epidemiological and clinical characteristics of 46 newly-admitted coronavirus disease 2019 cases in Beijing. Chin J Infect Dis 2020(00):E011-E11. doi:10.3760/cma.j.cn311365-20200219-00086. Article in Chinese.

78. Liu C, Jiang ZC, Shao CX, et al. Preliminary study of the relationship between novel coronavirus pneumonia and liver function damage: a multicenter study Chin J Hepatol 2020(02):148-52. doi: 10.3760/cma.j.issn.1007-3418.2020.02.000. Article in Chinese.

79. Zhong NS, Zeng GQ. What we have learnt from SARS epidemics in China. BMJ 2006;333(7564):389-91. doi: 10.1136/bmj.333.7564.389

80. Hsu LY, Lee CC, Green JA, et al. Severe acute respiratory syndrome (SARS) in Singapore: clinical features of index patient and initial contacts. Emerg Infect Dis 2003;9(6):713. doi: 10.3201/eid0906.030264

81. Lee N, Hui D, Wu A, et al. A major outbreak of severe acute respiratory syndrome in Hong Kong. N Engl J Med 2003;348(20):1986-94. doi: 10.1056/NEJMoa030685

82. Assiri A, Al-Tawfiq JA, Al-Rabeeah AA, et al. Epidemiological, demographic, and clinical characteristics of 47 cases of Middle East respiratory syndrome coronavirus disease from Saudi Arabia: a descriptive study. Lancet Infect Dis 2013;13(9):752-61. doi:10.1016/S1473-3099(13)70204-4 
medRxiv preprint doi: https://doi.org/10.1101/2020.03.07.20032573; this version posted March 12, 2020. The copyright holder for this preprint (which was not certified by peer review) is the author/funder, who has granted medRxiv a license to display the preprint in perpetuity.

All rights reserved. No reuse allowed without permission.

83. WHO. Summary of probable SARS cases with onset of illness from 1 November 2002 to 31 July 2003. https://www.who.int/csr/sars/country/table2004_04_21/en/ Last accessed: March 05, 2020

84. WHO. MERS Monthly Report November 2019.

https://www.who.int/emergencies/mers-cov/en/ Last accessed: March 05, 2020

85. Guidelines for the Diagnosis and Treatment of Novel Coronavirus (2019-nCoV)

Infection by the National Health Commission (Trial Version 7). Available at: http://www.gov.cn/zhengce/zhengceku/2020-03/04/content_5486705.htm

86. Wong RSM, Wu A, To KF, et al. Haematological manifestations in patients with severe acute respiratory syndrome: retrospective analysis. BMJ 2003;326(7403):1358-1362. doi: 10.1136/bmj.326.7403.1358

87. Wang C, Horby PW, Hayden FG, et al. A novel coronavirus outbreak of global health concern. Lancet 2020;395(10223):470-473. doi: 10.1016/S0140-6736(20)30185-9 
Table 1. General information of the identified literatures.

\begin{tabular}{|c|c|c|c|c|c|c|}
\hline Reference & $\begin{array}{c}\text { Time for Enrollment } \\
\text { (Y/M/D) }\end{array}$ & Country/Region & Study type & $\begin{array}{c}\text { Target } \\
\text { population }\end{array}$ & $\mathbf{N}$ & $\begin{array}{c}\text { Quality } \\
\text { score }\end{array}$ \\
\hline Holshue et al. $^{12}$ & 2020.01 .19 & Snohomish, USA & Case report & Adult & 1 & 6 \\
\hline Rothe et al. ${ }^{13}$ & 2020.01 .24 & Munich, Germany & Case report & Adult & 1 & 5 \\
\hline Kim et al. ${ }^{14}$ & 2020.01 .19 & Incheon, Korea & Case report & Adult & 1 & 5 \\
\hline Cuong et al. ${ }^{15}$ & 2020.01 .23 & Thanh Hoa, Vietnam & Case report & Adult & 1 & 5 \\
\hline Phan et al. ${ }^{16}$ & 2020.01 .22 & Ho Chi Minh, Vietnam & Case report & Adult & 1 & 6 \\
\hline Bastola et al. ${ }^{17}$ & 2020.01 .13 & Kathmandu, Nepal & Case report & Adult & 1 & 6 \\
\hline Pongpirul et al. ${ }^{18}$ & 2020.01 .20 & Bangkok, Thailand & Case report & Adult & 1 & 6 \\
\hline Kam et al. ${ }^{19}$ & 2020.02 .04 & Singapore & Case report & Children (Infant) & 1 & 5 \\
\hline Silverstein et al. ${ }^{20}$ & NA & Toronto, Canada, & Case report & Adult & 1 & 6 \\
\hline Albarello et al. ${ }^{21}$ & 2020.01 .29 & Rome, Italy & Case series & Adult & 2 & 7 \\
\hline Chen et al. ${ }^{22}$ & 2020.01 .27 & Hubei, China & Case report & Children & 1 & 5 \\
\hline Huang et al. ${ }^{23}$ & NA & Guangdong, China & Case report & Adult & 1 & 4 \\
\hline Cai et al. ${ }^{24}$ & 2020.01 .19 & Shanghai, China & Case report & Children & 1 & 5 \\
\hline Zhang et al. ${ }^{25}$ & 2019.12.27-2019.12.30 & Hubei, China & Case series & Adult & 2 & 7 \\
\hline Lin et al. ${ }^{26}$ & NA & Jiangxi, China & Case series & Adult & 2 & 5 \\
\hline Fang et al. ${ }^{27}$ & NA & Zhejiang, China & Case series & Adult & 2 & 4 \\
\hline Deng et al. ${ }^{28}$ & 2020.01.22-2020.01.31 & Shanxi, China & Case series & Children & 2 & 4 \\
\hline Yang et al. ${ }^{29}$ & $2020.01 .25-2020.02 .11$ & Guangdong, China & Case series & Adult & 3 & 7 \\
\hline Wang et al. ${ }^{30}$ & 2020.01.21-2020.01.24 & Shanghai, China & Case series & Adult & 4 & 7 \\
\hline Zeng et al. ${ }^{31}$ & 2020.02 .05 & Hubei, China & Case report & Children (Infant) & 1 & 4 \\
\hline $\mathrm{Xu}$ et al. ${ }^{32}$ & NA & Guangdong, China & Case report & Adult & 1 & 4 \\
\hline Li et al. ${ }^{33}$ & 2020.01 .29 & Henan, China & Case report & Adult (pregnant) & 1 & 6 \\
\hline Xie et al. ${ }^{34}$ & NA & Hunan, China & Case series & Adult & 5 & 6 \\
\hline
\end{tabular}




\begin{tabular}{|c|c|}
\hline Huang et al. ${ }^{35}$ & 2020.01 \\
\hline Yu et al. ${ }^{36}$ & 2020.01 .21 \\
\hline Pan et al. ${ }^{37}$ & 2020.01 .27 \\
\hline Hao et al. ${ }^{38}$ & NA \\
\hline Wei et al. ${ }^{39}$ & NA \\
\hline Hao et al. ${ }^{40}$ & NA \\
\hline $\mathrm{Xu}$ et al. ${ }^{41}$ & 2020.01 .21 \\
\hline Lei et al. ${ }^{42}$ & 2020.01 \\
\hline Liu et al. ${ }^{43}$ & 2020.01 \\
\hline Ruan et al. ${ }^{44}$ & 2020.01 .20 \\
\hline Chan et al. ${ }^{45}$ & $2020.01 .10-2020.01 .15$ \\
\hline Chen et al. ${ }^{46}$ & $2020.01 .20-2020.01 .31$ \\
\hline Wei et al. ${ }^{47}$ & $2019.12 .08-2020.02 .06$ \\
\hline Bai et al. ${ }^{48}$ & 2020.02 \\
\hline Cai et al. ${ }^{49}$ & $2020.01 .19-2020.02 .03$ \\
\hline Gao et al. ${ }^{50}$ & $2020.01 .21-2020.02 .4$ \\
\hline Zhang et al. ${ }^{51}$ & $2020.01 .18-2020.02 .03$ \\
\hline Feng et al. ${ }^{52}$ & $2019.01 .16-2020.02 .06$ \\
\hline Chang et al. ${ }^{53}$ & $2020.01 .16-2020.01 .29$ \\
\hline Li et al. ${ }^{54}$ & $2020.01 .19-2020.01 .26$ \\
\hline Yang et al. ${ }^{55}$ & $2020.01 .01-2020.02 .03$ \\
\hline Li et al. ${ }^{56}$ & $2020.01-2020.02$ \\
\hline Chung et al. ${ }^{57}$ & $2020.01 .18-2020.01 .27$ \\
\hline Chen et al. ${ }^{58}$ & $2020.01 .14-2020.01 .29$ \\
\hline Huang et al. ${ }^{6}$ & 2019.12.16-2020.01.02 \\
\hline Song et al. ${ }^{59}$ & $2020.01 .20-2020.01 .27$ \\
\hline
\end{tabular}

$\begin{array}{cc}\text { Taiwan } & \text { Case series } \\ \text { Shanghai, China } & \text { Case series } \\ \text { Guangdong, China } & \text { Case series } \\ \text { Shanxi, China } & \text { Case report } \\ \text { Jiangxi, China } & \text { Case report } \\ \text { Shanxi, China } & \text { Case report } \\ \text { Beijing, China } & \text { Case report } \\ \text { Gansu, China } & \text { Case report } \\ \text { Hunan, China } & \text { Case report } \\ \text { Guangdong, China } & \text { Case report } \\ \text { Guangdong, China } & \text { Case series } \\ \text { Hubei, China } & \text { Case series } \\ \text { 7 provinces , China } & \text { Case series } \\ \text { Gansu, China } & \text { Case series } \\ \text { 4 provinces }{ }^{\S} \text {, China } & \text { Case series } \\ \text { Shanxi, China } & \text { Case series } \\ \text { Beijing, China } & \text { Case series } \\ \text { Guangdong, China } & \text { Case series } \\ \text { Beijing, China } & \text { Case series } \\ \text { Beijing, China } & \text { Case-control } \\ \text { Shanghai, China } & \text { Case-control } \\ \text { Hubei, China } & \text { Case-control } \\ \text { 3 provinces\#, China } & \text { Cross-sectional } \\ \text { Hubei, China } & \text { Cross-sectional } \\ \text { Hubei, China } & \text { Cross-sectional } \\ \text { Shanghai, China } & \text { Cross-sectional }\end{array}$

$\begin{array}{ccc}\text { Adult } & 2 & 7 \\ \text { Adult } & 4 & 6 \\ \text { Adult/children } & 3 & 6 \\ \text { Adult } & 1 & 4 \\ \text { Adult } & 1 & 6 \\ \text { Adult } & 1 & 4 \\ \text { Adult } & 1 & 6 \\ \text { Adult } & 1 & 4 \\ \text { Adult } & 1 & 4 \\ \text { Adult } & 1 & 4 \\ \text { Adult/children } & 6 & 6 \\ \text { Adult (pregnant) } & 9 & 6 \\ \text { Children } & 9 & 6 \\ \text { Adult } & 7 & 6 \\ \text { Children } & 10 & 6 \\ \text { Adult } & 11 & 8 \\ \text { Adult/children } & 9 & 6 \\ \text { Children } & 15 & 6 \\ \text { Adult } & 13 & 7 \\ \text { Adult } & 9 & 7 \\ \text { Adult } & 10 & 7 \\ \text { Adult } & 31 & 7 \\ \text { Adult } & 21 & 5 \\ \text { Adult } & 29 & 7 \\ \text { Adult } & 41 & 8 \\ \text { Adult } & 51 & 7\end{array}$




\begin{tabular}{|c|c|c|c|c|c|c|}
\hline Chen et al. ${ }^{7}$ & 2020.01.01-2020.01.20 & Hubei, China & Cross-sectional & Adult & 99 & 8 \\
\hline Huang et al. ${ }^{60}$ & 2020.01-NA & Hubei, China & Cross-sectional & Adult & 103 & 6 \\
\hline Kui et al. ${ }^{61}$ & $2019.12 .30-2020.01 .24$ & Hubei, China & Cross-sectional & Adult & 137 & 6 \\
\hline Wang et al. ${ }^{8}$ & $2020.01 .01-2020.01 .28$ & Hubei, China & Cross-sectional & Adult & 138 & 8 \\
\hline Zhao et al. ${ }^{62}$ & $2020.01 .22-2020.02 .05$ & Guangxi, China & Cross-sectional & Adult/children & 28 & 8 \\
\hline Xu et al. ${ }^{63}$ & 2020.01.22-2020.01.29 & Henan, China & Cross-sectional & Adult & 23 & 6 \\
\hline Xu et al. ${ }^{9}$ & $2020.01 .10-2020.01 .26$ & Zhejiang, China & Cross-sectional & Adult/children & 62 & 8 \\
\hline Shi et al. ${ }^{64}$ & $2019.12 .20-2020.01 .23$ & Hubei, China & Cross-sectional & Adult & 81 & 8 \\
\hline Wu et al. ${ }^{65}$ & $2020.01 .22-2020.02 .14$ & Jiangsu, China & Cross-sectional & Adult & 80 & 7 \\
\hline $\mathrm{Xu}$ et al. ${ }^{66}$ & 2020.01.23-2020.02.04 & Guangdong, China & Cross-sectional & Adult & 90 & 7 \\
\hline Yang et al. ${ }^{67}$ & $2020.01 .17-2020.02 .10$ & Zhejiang, China & Cross-sectional & Adult & 149 & 6 \\
\hline Wu et al. ${ }^{68}$ & 2020.01-2020.02 & Chongqing, China & Cross-sectional & Adult & 80 & 5 \\
\hline Zhang et al. ${ }^{69}$ & $2020.01 .16-2020.02 .03$ & Hubei, China & Cross-sectional & Adult & 140 & 6 \\
\hline Yang et al. ${ }^{70}$ & 2019.12-2020.01.26 & Hubei, China & Cross-sectional & Adult & 52 & 8 \\
\hline $\mathrm{Xu}$ et al. ${ }^{71}$ & $2020.01-2020.02$ & Beijing, China & Cross-sectional & Children & 50 & 8 \\
\hline Liu et al. ${ }^{72}$ & $2020.01 .13-2020.01 .31$ & Jiangsu, China & Cross-sectional & Adult & 33 & 8 \\
\hline Bernheim et al. ${ }^{73}$ & $2020.01 .18-2020.02 .02$ & 4 provinces $^{\mathfrak{t}}$, China & Cross-sectional & Adult & 121 & 6 \\
\hline Tian et al. ${ }^{74}$ & NA-2020.02.10 & Beijing, China & Cross-sectional & Adult & 262 & 8 \\
\hline Liu et al. ${ }^{75}$ & $2019.12 .30-2020.01 .15$ & Hubei, China & Cross-sectional & Adult & 78 & 6 \\
\hline Wan et al. ${ }^{76}$ & $2020.01 .26-2020.02 .05$ & Chongqing, China & Cross-sectional & Adult/children & 153 & 6 \\
\hline Wen et al. ${ }^{77}$ & $2020.01 .20-2020.02 .08$ & Beijing, China & Cross-sectional & Adult/children & 46 & 6 \\
\hline Liu et al. ${ }^{78}$ & $2020.01 .23-2020.02 .08$ & 7 provinces $^{\&}$, China & Cross-sectional & Adult & 32 & 6 \\
\hline Guan et al. ${ }^{10}$ & $2019.12 .11-2020.01 .29$ & 30 provinces", China & Cross-sectional & Adult/children & 1099 & 8 \\
\hline
\end{tabular}

NA: not available; *, including Beijing, Hainan, Guangdong, Anhui, Shanghai, Guizhou and Zhejiang; §, including Shanghai, Shandong, Hainan, Anhui; \#, including Guangdong, Shanghai and Jiangxi; £, including Guangdong, Jiangxi, Sichuan and Guangxi; \&, including Gansu, Zhejiang, Jiangsu, Hebei, Liaoning, Shanxi and Guangdong; II, including all provinces or provincial municipalities except Hong Kong, Macau and Tibet. 
Table 2: Summary of the demographics and clinical characteristics of patients with COVID-19.

\begin{tabular}{|l|c|}
\hline \multicolumn{2}{|l|}{ Demographics } \\
\hline Total number of cases & 3470 \\
\hline Male\% & $1822 / 3467,52.6 \%$ \\
\hline Age (range) & 17 -day to 92-year \\
\hline Smokers\% $\#$ & $208 / 1573,13.2 \%$ \\
\hline Transmission exposures\% ${ }^{*}$ & $2182 / 2873,76.0 \%$ \\
\hline Coexisting underlying disorders $\mathbf{( 8 8 8 / 2 8 1 8 , 3 1 . 5 \% )}$ \\
\hline Diabetes & $206 / 2818,7.3 \%$ \\
\hline Hypertension & $376 / 2818,13.3 \%$ \\
\hline Cardiovascular and cerebrovascular diseases & $233 / 2818,8.3 \%$ \\
\hline Chronic obstructive pulmonary disease (COPD) & $40 / 2818,1.4 \%$ \\
\hline Chronic liver diseases & $58 / 2818,2.0 \%$ \\
\hline Chronic renal diseases & $20 / 2818,0.71 \%$ \\
\hline Malignancy & $43 / 2818,1.5 \%$ \\
\hline Digestive system disease & $32 / 2818,1.1 \%$ \\
\hline Other chronic diseases ${ }^{\S}$ & $148 / 2818,5.3 \%$ \\
\hline Complications & $29 / 1347,(2.2 \%)$ \\
\hline ARDS & $30 / 1399,(2.1 \%)$ \\
\hline Shock & $185 / 1612,(11.5 \%)$ \\
\hline Acute renal failure & $100 / 2682,(3.7 \%)$ \\
\hline ICU admission & \\
\hline Case fatality & \\
\hline
\end{tabular}

Notes: \#, current smokers and ex-smokers; *, being Wuhan residents or ever travelled to Wuhan within 14 days; §, Including thyroid disorders, HIV, endocrine system disease, nervous system disease, etc. 
medRxiv preprint doi: https://doi.org/10.1101/2020.03.07.20032573; this version posted March 12, 2020. The copyright holder for this preprint (which was not certified by peer review) is the author/funder, who has granted medRxiv a license to display the preprint in perpetuity.

All rights reserved. No reuse allowed without permission.

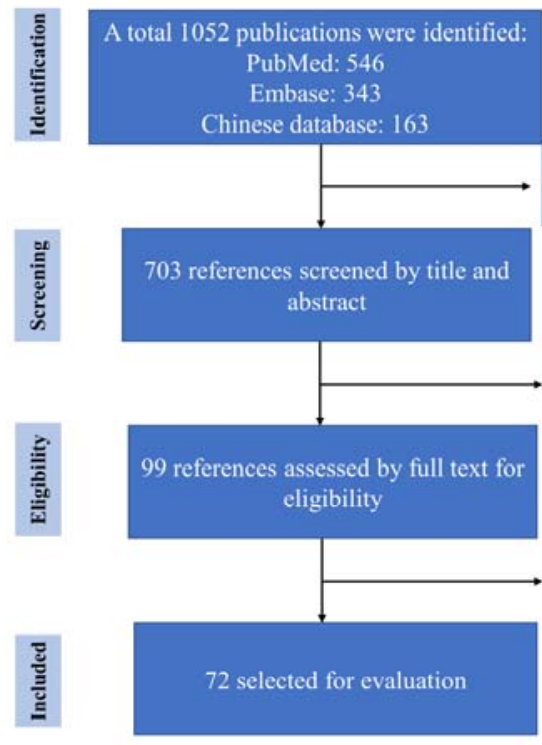

349 references excluded:

-Duplicated references

604 references excluded:

-Irrelevant contents

Figure 1 PRISMA flow chart of literature searching and selection. 
medRxiv preprint doi: https://doi.org/10.1101/2020.03.07.20032573; this version posted March 12, 2020. The copyright holder for this preprint (which was not certified by peer review) is the author/funder, who has granted medRxiv a license to display the preprint in perpetuity. All rights reserved. No reuse allowed without permission.

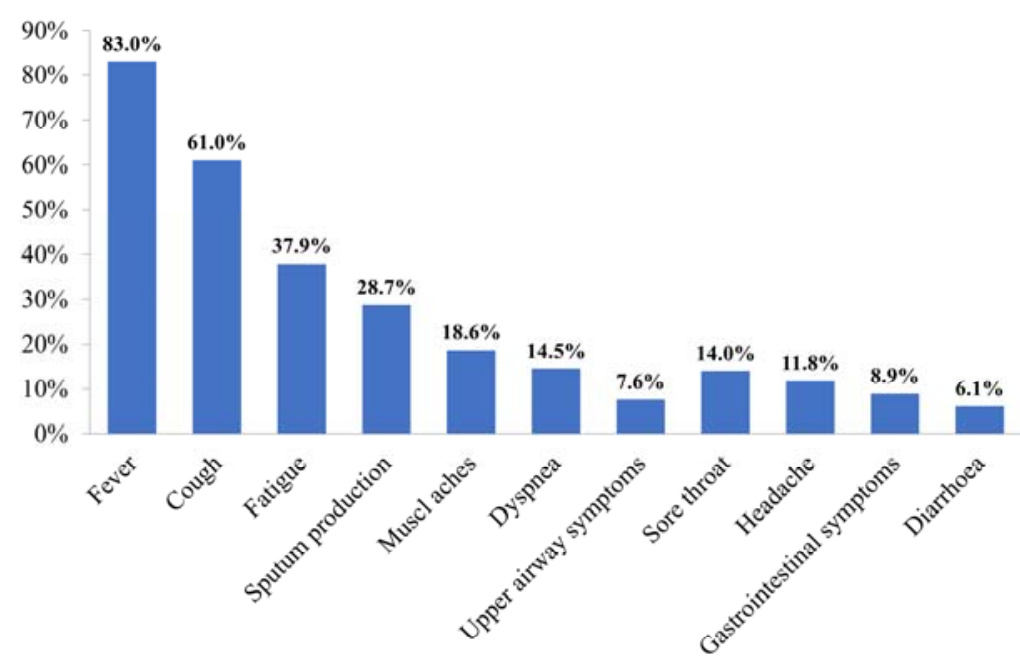

Figure 2: Clinical symptoms of patients with COVID-19 
medRxiv preprint doi: https://doi.org/10.1101/2020.03.07.20032573; this version posted March 12, 2020. The copyright holder for this preprint (which was not certified by peer review) is the author/funder, who has granted medRxiv a license to display the preprint in perpetuity. All rights reserved. No reuse allowed without permission.

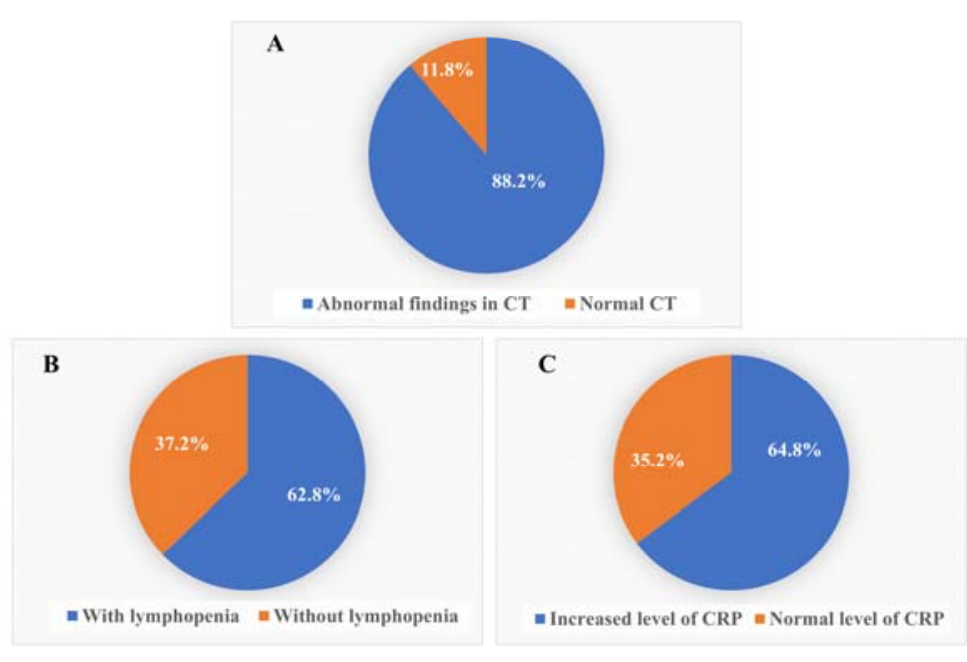

Figure 3: Findings of radiography (A) and laboratory blood tests $(\mathrm{B}, \mathrm{C})$ in patients with COVID-19 